\title{
Kualitas Layanan Kesehatan Pasien Peserta Badan Penyelenggara Jaminan Sosial (BPJS) di Rumah Sakit Universitas Hasanuddin
}

\author{
Mariati Rahman \\ Universitas Pepabri, Makassar
}

\begin{abstract}
ABSTRAK
Penelitian ini bertujuan mendeskripsikan, menganalisis, dan menginterpretasikan pelayanan pasien peserta BPJS di Rumah Sakit UNHAS. Jenis penelitian ini adalah kualitatif deskriptif dengan pendekatan fenomenologi, yang mengkaji dan mengungkapkan makna konsep atau fenomena dan pengalaman tentang pelayanan yang dialami pasien peserta BPJS berdasarkan apa yang terjadi di Rumah Sakit UNHAS. Teknik pengumpulan data dilakukan dengan wawancara, observasi, dan telaah dokumentasi. Sumber data diperoleh dari 10 informan kunci. Teknik analisis data mengunakan model interatif Miles dan Huberman (2007) yakni reduksi data, penyajian data, verifikasi data dan kesimpulan. Hasil Penelitian menemukan bahwa Kualitas Layanan Kesehatan bagi peserta BPJS di Rumah Sakit UNHAS belum optimal, karena masih ada hak-hak pasien BPJS belum terakomodasi terutama pada dimensi responsivitas (daya tanggap) petugas Rumah Sakit yaitu pasien menunggu layanan lebih dari satu jam. Dimensi responsibilitas yaitu dokter memberi resep obat, kadang tidak tersedia di apotik, dan kamar Inap tidak mencukupi/penuh untuk pasien BPJS.
\end{abstract}

Kata kunci: Kualitas, Layananan, BPJS, Kesehatan

\begin{abstract}
This study aims to describe, analyze, and interpret patient services BPJS participants at UNHAS Hospital. This type of research is qualitative descriptive with phenomenology approach, which examines and expresses the meaning of concept or phenomenon and experience about the service experienced by BPJS participant patients based on what happened at UNHAS Hospital. Technique of data collecting is done by interview, observation, and documentation study. Data sources were obtained from 10 key informants. Data analysis technique using Interactive model of Miles and Huberman (2007) ie data reduction, data presentation, data verification and conclusion. The results of the study found that the quality of health services for BPJS participants at the UNHAS Hospital was not optimal, because there are still patient rights BPJS has not been accommodated, especially on the dimensions of responsiveness (responsiveness) of hospital staff patients waiting for more than one hour service. Dimensions of responsibility that doctors prescribe drugs, sometimes not available in pharmacies, and inpatient rooms are not sufficient / full for patients BPJS.
\end{abstract}

Keywords: Quality, Service, BPJS, Health

\section{PENDAHULUAN}

Pelayanan publik merupakan salah satu persoalan krusial yang seakan tidak ada habisnya, substansi pelayanan publik selalu dikaitkan dengan suatu kegiatan yang dilakukan oleh seseorang atau kelompok orang atau instansi tertentu untuk memberikan bantuan dan 
Mariati Rahman, Kualitas Layanan Kesehatan Pasien Peserta Badan Penyelenggara Jaminan Sosial (BPJS) di Rumah Sakit Universitas Hasanuddin $\mid 31$

kemudahan kepada masyarakat dalam rangka mencapai tujuan tertentu (Randy, 2007; Wahyudi, 2011). Pelayanan publik ini menjadi semakin penting karena senantiasa berhubungan dengan khalayak masyarakat ramai yang memiliki keaneka ragaman kepentingan dan tujuan (Suryono, 2001). Oleh karena itu institusi pelayanan publik dapat dilakukan oleh pemerintah maupun nonpemerintah. Salah satu diantaranya adalah pelayanan kesehatan oleh Badan Penyelenggara Jaminan Sosial (BPJS).

Sejak awal Tahun 2014 pemerintah mewajibkan semua penduduk menjadi peserta Jaminan Kesehatan Nasional-Badan Penyelenggara Jaminan Sosial (JKN-BPJS). Kewajiban menjadi peserta pada satu sisi memberi manfaat. Namun di sisi lain, program JKN-BPJS memiliki banyak masalah yang hingga kini belum teratasi, terutama pada kualitas pelayanan. Mutu pelayanan hanya dapat diketahui apabila telah dilakukan penilaian-penilaian, baik terhadap tingkat kesempurnaan, sifat, wujud, ciri-ciri pelayanan kesehatan dan kepatuhan terhadap standar pelayanan (Firmansyah, n.d.; Wardani, 2009; Yohana, 2009). Setiap orang mempunyai kriteria penilaian untuk kualitas pelayanan dan mempunyai cara-cara penilaian yang berbeda. Salah satu Indikator penilaian tentang kualitas pelayanan menurut Zeithaml, Parasuraman, \& Berry (1990) adalah responsivitas. Dalam penelitian ini dipokuskan pada responsivitas karyawan rumah sakit UNHAS terhadap pasien peserta JKN - BPJS.

Undang-Undang BPJS menentukan bahwa,"BPJS Kesehatan berfungsi menyelenggarakan program jaminan kesehatan." Jaminan kesehatan menurut UU SJSN diselenggarakan secara nasional berdasarkan prinsip asuransi sosial dan prinsip ekuitas, dengan tujuan menjamin agar peserta memperoleh manfaat pemeliharaan kesehatan dan perlindungan dalam memenuhi kebutuhan dasar kesehatan.

Upaya peningkatan kualitas layanan kesehatan dapat dilakukan dengan cara memperbaiki manajemen kualitas jasa (service quality management), yakni upaya meminimasi kesenjangan (gap) antara tingkat layanan yang disediakan organisasi dengan harapan dan keinginan customer (masyarakat pengguna). Keberhasilan sebuah rumah sakit bukan dilihat dari fasilitasnya (output) tetapi dari kemanfaatan langsung atas keberadaan fasilitas tersebut bagi masyarakat (outcome). Selanjutnya, monitoring kinerja perlu dilakukan sebagai alat untuk mengevaluasi apakah pelayanan kesehatan dan program-program organisasi penyedia layanan kesehatan ini sudah sesuai dengan apa yang dibutuhkan masyarakat. Monitoring kinerja dapat juga digunakan untuk mengidentifikasi apakah tingkat kualitas pelayanan publik sudah lebih baik daripada sebelumnya. Dengan dilakukan monitoring kinerja secara berkelanjutan, sebenarnya akan membantu meningkatkan kualitas organisasi layanan publik itu sendiri.

Jika organisasi layanan publik ini adalah Rumah Sakit, maka monitoring kinerja berarti menjawab pertanyaan tentang apakah rumah sakit tersebut sudah mengelola sumber daya secara optimal dan menyediakan layanan terbaik untuk kepuasan para pengguna atau masyarakat. Adanya perbaikan kualitas pelayanan dapat diidentifikasi dari menurunnya tingkat komplain dari pasien atau pengguna, kepuasan pasien, meningkatnya jumlah pasien dan meningkatnya kepercayaan masyarakat umum. Organisasi layanan publik seperti rumah sakit ini harus berorientasi pada outcome dan bukan sekedar input dan output. Jadi, indikator kinerja atas kualitas pelayanan sebuah rumah sakit bukan sekedar jumlah dokter per pasien, jumlah kamar untuk setiap kelas atau jumlah pengeluaran yang tidak melebihi anggaran tetapi yang lebih 
penting adalah tingkat kepuasan yang dirasakan oleh para pengguna jasa Rumah Sakit tersebut karena harapan dan kebutuhannya dapat tercapai.

Masih sering terjadi hingga saat ini organisasi layanan publik yang tidak berorientasi pada masyarakat pengguna (apa yang dibutuhkan oleh pengguna). Artinya, pengguna (user/customer) bukan menjadi perhatian utama, dengan pertimbangan bahwa mereka pasti membutuhkan jasa atau layanan publik ini. Tanpa harus dengan pelayanan yang baik pun masyarakat pasti akan datang. Pola pikir (mind set) seperti ini sudah sepantasnya diubah.

\section{METODE PENELITIAN}

Penelitian ini menggunakan pendekatan kualitatif yang dilaksanakan di Rumah Sakit UNHAS, sebagai informan kunci adalah Pasien BPJS, Direktur Pelayanan, Kabid Pelayanan. Triangulasi adalah BPJS Kesehatan: Kepala Cabang Makassar dan pasien peserta BPJS. Jenis penelitian ini adalah deskriptif dengan pendekatan fenomenologi, yang mengkaji dan mengungkap makna konsep atau fenomena dan pengalaman individu tentang pelayanan pasien BPJS yakni Pelayanan kesehatan yang dialami oleh pasien, dan merupakan bahagian dari informan kunci. Penelitian ini dilakukan dalam situasi yang alami, sehingga tidak ada batasan dalam memaknai atau memahami tentang situasi informan. Selanjutnya fakta dan data yang ditemukan dilapangan, diinterpretasi, dianalisis dan dideskripsikan secara holistik. Teknik pengumpulan data dilakukan dengan wawancara, observasi, dan telaah dokumentasi. Sumber data diperoleh dari 10 informan kunci. Teknik analisis data mengunakan model (Miles \& Huberman, 2007) yakni reduksi data, penyajian data, verifikasi data dan kesimpulan.

\section{HASIL PENELITIAN PEMBAHASAN}

Pelaksanaan kegiatan pelayanan di Rumah Sakit UNHAS yakni layanan rawat Jalan dan rawat Inap. Poliklinik RS Unhas Makassar melayani pasien 6 hari dalam seminggu termasuk pasien BPJS (Senin s/d Sabtu) dari pukul 07-30 s/d 14.00. Ditangani oleh dokter umum, dan dokter spesialis yang handal dengan dibantu oleh tenaga paramedic profesional dan terlatih di bidangnya. Poli Klinik rawat jalan terletak dilantai I gedung Cancer Center RS Unhas Makassar dengan layanan : Poli Interna, Poli THT, Poli Anak, Poli Umum, Poli Psikiatri \& Gizi, Poli Bedah, Poli Fisioterapi, Poli Ongkologi, Poli Laktasi, Poli Kardiologi, Poli Ortopedi \& Traumatologi, Poli Saraf \& EEG, Poli Klinik Nyeri dan Paliatif, Poli Klinik Mata, Poli Klinik Kulit dan Kelamin.

Layanan Rawat inap adalah salah satu jenis pelayanan kesehatan bagi pasien yang memerlukan tindakan medis, keperawatan dan non medis lebih lanjut, (dalam kurun waktu tertentu) yang membutuhkan perawatan rawat inap di rumah sakit (hospitalization), hal ini dikarenakan penyakit yang diderita oleh pasien dianggap memerlukan perawatan yang intensif oleh tenaga medis, keperawatan dan non medis untuk mencapai kesehatan yang optimal (Undang-undang RI No.44 Tahun 2009).

Pelaksanaan pelayanan medis kepada seorang pasien untuk tujuan observasi, diagnosis, pengobatan, rehabilitasi dan pelayanan kesehatan lainnya tanpa mengharuskan pasien tersebut dirawat inap. Instalasi Rawat Jalan dipimpin oleh seorang kepala instalasi yang mempunyai tugas dan kewenangan menyediakan fasilitas penyelenggaraan kegiatan pelayanan poliklinik 
Mariati Rahman, Kualitas Layanan Kesehatan Pasien Peserta Badan Penyelenggara Jaminan Sosial (BPJS) di Rumah Sakit Universitas Hasanuddin 133

rawat jalan dari berbagai disiplin ilmu kedokteran klinik. Layanan Medis lainnya: termasuk Trauma Center adalah sebuah fasilitas pelayanan kesehatan yang khusus menangani pasien trauma di rumah sakit, pelayanan tersebut dilakukan oleh beberapa dokter ahli seperti dokter ahli bedah, dokter anastesi serta perawat khusus dan menyediakan peralatan pendukung hidup lanjut, secara cepat yang siap dalam 24 jam. Penangan pasien trauma di trauma center didukung beberapa instalasi dan unit pelayanan yang kegiatannya saling mendukung, instalasi dan unit pendukung Trauma Center antara lain : Instalasi Rawat Darurat (IRD), ambulance, laboratorium, radiologi, kamar operasi, Intensif Care Unit (ICU), rehabilitas medic, apotek dan rehabilitasi medik hingga pasca hospital yang terintegrasi dalam suatu sistem yang terkait. Selain itu, juga dilengkapi dengan fasilitas kamar.

Apabila fasilitas yang disediakan serta jasa yang diterima atau dirasakan sesuai dengan yang diharapkan maka kualitas dipersepsikan baik dan memuaskan (Optimal). Jika fasilitas/jasa yang diterima melampaui harapan pelanggan, maka kualitas jasa dipersepsikan sebagai kualitas jasa yang ideal (sangat optimal). Sebaliknya jika fasilitas/jasa yang diterima lebih rendah dari pada yang diharapkan maka kualitas jasa dipersepsikan buruk (tidak Optimal). Terkait pada fasilitas yang tersedia juga ada beberapa data sekunder (dokumen RS) yang ditampilkan, kemudian data tersebut diolah menjadi data primer, untuk mendukung data wawancara dengan informan yaitu data rawat jalan dan data rawat inap, terdapat pada tabel 1.

Berdasarkan data Tri wulan I tersebut menunjukkan bahwa animo pasien BPJS untuk pelayanan pada poliklinik non bedah dan poliklinik bedah RS UNHAS, sangat tinggi (86\%$88 \%)$ jika dibanding pasien Umum, ( $12 \%-14 \%)$ dan pasien dari kooporasi tidak ada ( $0 \%)$. sejak berlakunya kartu BPJS. Data pada triwulan II tersebut di atas menunjukkan bahwa animo pasien BPJS untuk mendapatkan pelayanan kesehatan, di RS UNHAS sangat tinggi yaitu (94\% dan 88\%) jika dibanding pasien Umum, ( $6 \%$ - 11\%) dan pasien dari koorporasi hanya ( $1 \%)$, sejak diberlakunya kartu BPJS. Begitu pula pada triwulan III kurang lebih sama dengan triwulan II dan I, animo pasien BPJS untuk berobat pada Rumah Sakit UNHAS masih sangat tinggi ( $96 \%$ dan $82 \%$ ), sedangkan untuk pasien umum hanya (4\% dan 17\%), selebihnya dari pasien koorporasi sebanyak (1\%) itu terlihat pada poliklinik non bedah dan poliklinik bedah.

Layanan yang paling diharapkan oleh pasien adalah daya tanggap (responsiveness), yaitu adanya keinginan para staf untuk membantu para pasien dan memberikan pelayanan dengan tanggap. Ada empat indikator: 1) Dokter, perawat, petugas administrasi mempunyai keinginan untuk memberikan pelayanan kepada pasien secepatnya, 2) Dokter tepat dalam memberikan resep kepada pasien dan tersedia di Apotik Rumah Sakit. 3) Petugas administrasi cepat tanggap dalam menerima setiap pasien, dan 4) Petugas administrasi mampu mendata pasien dengan tepat dan cepat.

Berdasarkan hasil wawancara mengenai responsivitas pelayanan rumah sakit menurut ungkapan pasien di poli bedah untuk rawat inap mengatakan bahwa: dalam proses pelayanan, pasien harus menunggu lama untuk memeroleh kamar rawat nginap. Menurut salah satu pasien (Irda) mengeluhkan dan menceritakan, sampai sembilan hari nunggu antrian baru dapat kamar kelas I (nomor antrian 80), kasus penyakit yang dideritanya adalah kanker, karena menurut dokter bahwa pasien mendapatkan tindakan operasi apabile telah memeroleh kamar. Selanjutnya, pasien tersebut, melapor di kantor perwakilan BPJS yang lokasi / bertempat di rumah sakit Unhas tempat pasien memeroleh rujukan. Dari penjelasan pasien menunjukan 
bahwa resposivitas petugas BPJS tidak tanggap terhadap keluhan yang dirasakan oleh banyak pasien. Responsivitas sebagai salah satu indikator kualitas layanan yang menggambarkan kemampuan organisasi publik dalam menjalankan visi dan misinya, terutama untuk memenuhi kebutuhan masyarakat. Selain itu, kenyamanan yang diterima pasien BPJS dengan fasilitas yang telah disediakan oleh rumah Sakit Unhas tidak sebanding dengan rasa sakit ketika pasien menunggu giliran tindakan operasi dari Dokter. Dengan demikian dapat dikatakan bahwa kualitas layanan kesehatan peserta BPJS di Rumah Sakit UNHAS belum optimal karena masih ada keluhan dari pasien yakni: menunggu lebih dari satu jam bahkan berhari-hari baru mendapat layanan medis, Dokter memberi resep obat (obat gratis) kadang tidak tersedia di apotik, kamar Inap yang dibutuhkan oleh pasien BPJS Kadang tidak tersedia/sudah penuh.

\section{SIMPULAN}

Rumah sakit sebagai organisasi pelayanan publik mempunyai ciri public accuntability, dimana setiap warga negara mempunyai hak untuk mengevaluasi kualitas pelayanan yang mereka terima dari rumah sakit. Adalah sangat sulit untuk menilai kualitas suatu pelayanan tanpa mempertimbangkan peran masyarakat sebagai penerima pelayanan dan aparat pelaksana pelayanan itu sebagai pemberi layanan yakni pihak BPJS kesehatan. Evaluasi yang berasal dari pengguna pelayanan, merupakan elemen pertama dalam analisis kualitas pelayanan publik. Elemen kedua dalam analisis adalah kemudahan suatu pelayanan dikenali baik sebelum dalam proses atau setelah pelayanan itu diberikan. Responsiveness (kesanggupan untuk membantu dan menyediakan pelayanan secara cepat dan tepat, serta tanggap terhadap keinginan konsumen).

\section{DAFTAR PUSTAKA}

Firmansyah, A. (n.d.). Efektivitas Peran dan Fungsi Komite Sekolah Berdasarkan Lampiran II KepMendiknas No. 044/U/2002 di SDN Sumbersari III Jember.

Miles, M. B., \& Huberman, A. M. (2007). Qualitative Data Analysis (terjemahan). Jakarta: UI Press.

Randy, R. W. (2007). Manajemen Pemberdayaan. Elex Media Komputindo.

Suryono, A. (2001). Budaya Birokrasi Pelayanan Publik. Jurnal Ilmiah Administrasi Negara, $1(2), 49-58$.

Wahyudi, G. (2011). Kajian Tentang Penyuapan Sebagai Salah Satu Bentuk Tindak Pidana Korupsi. Universitas Sebelas Maret.

Wardani, D. S. (2009). Kepatuhan Bidan Praktek Swasta Dalam Pelaporan Pencatatan Pelayanan KIA Di Kabupaten Blitar Propinsi Jawa Timur Tahun 2009. Program Pasca Sarjana Universitas Diponegoro.

Yohana, A. (2009). Analisis Harapan Dan Kepuasan Pasien Rawat Inap Penyakit Dalam Terhadap Mutu Pelayanan Dokter Spesialis Di Rsi Sunan Kudus. program Pascasarjana Universitas Diponegoro.

Zeithaml, V. A., Parasuraman, A., \& Berry, L. L. (1990). Delivering quality service: Balancing customer perceptions and expectations. Simon and Schuster. 
Mariati Rahman, Kualitas Layanan Kesehatan Pasien Peserta Badan Penyelenggara Jaminan Sosial

(BPJS) di Rumah Sakit Universitas Hasanuddin 135

Tabel 1

Kunjungan Rawat Jalan Rumah Sakit Universitas Hasanuddin

Triwulan I Tahun 2014 (74 Hr)

\begin{tabular}{|c|c|c|c|c|c|c|c|c|}
\hline No & $\begin{array}{l}\text { Jenis } \\
\text { Pelayanan }\end{array}$ & Baru & Lama & Jumlah & Umum & BPJS & Korporasi & $\begin{array}{l}\text { Rata- } \\
\text { rata } \\
\text { Perhari }\end{array}$ \\
\hline \multirow[t]{10}{*}{1} & $\begin{array}{l}\text { Poliklinik } \\
\text { Bedah }\end{array}$ & & & & & & & \\
\hline & Orthopedi & 124 & 271 & 395 & 103 & 292 & 0 & 5,34 \\
\hline & Digestif & 44 & 152 & 196 & 12 & 184 & 0 & 2,65 \\
\hline & Saraf & 32 & 87 & 119 & 12 & 107 & 0 & 1,61 \\
\hline & Anak & 17 & 54 & 71 & 6 & 65 & 0 & 0,96 \\
\hline & Onkologi & 200 & 803 & 1003 & 102 & 901 & 0 & 13,55 \\
\hline & Plastik & 8 & 17 & 25 & 6 & 19 & 0 & 0,34 \\
\hline & Urologi & 69 & 392 & 461 & 25 & 432 & 4 & 6,23 \\
\hline & $\begin{array}{l}\text { Thorax \& } \\
\text { Cardio }\end{array}$ & 3 & 26 & 29 & 3 & 26 & 0 & 0,39 \\
\hline & JUMLAH & 497 & 1802 & 2299 & 269 & 2026 & 4 & 31,07 \\
\hline \multirow[t]{17}{*}{2} & $\begin{array}{l}\text { Poliklinik Non } \\
\text { Bedah }\end{array}$ & & & & & & & \\
\hline & Saraf & 163 & 478 & 641 & 63 & 578 & 0 & 8,66 \\
\hline & Anak & 104 & 138 & 242 & 77 & 162 & 3 & 3,27 \\
\hline & Interna & 847 & 1543 & 2390 & 269 & 2121 & 0 & 32,30 \\
\hline & THT & 263 & 293 & 556 & 164 & 388 & 4 & 7,51 \\
\hline & Obgyn & 136 & 210 & 346 & 95 & 247 & 4 & 4,68 \\
\hline & Psikiatrik/ Jiwa & 9 & 26 & 35 & 10 & 25 & 0 & 0,47 \\
\hline & Gizi & 6 & 0 & 6 & 0 & 6 & 0 & 0,08 \\
\hline & Kulkel & 64 & 104 & 168 & 66 & 89 & 13 & 2,27 \\
\hline & Mata & 395 & 1567 & 1962 & 202 & 1753 & 7 & 26,51 \\
\hline & Umum & 31 & 63 & 94 & 46 & 48 & 0 & 1,27 \\
\hline & Cardio & 238 & 169 & 407 & 25 & 381 & 1 & 5,50 \\
\hline & Klinik Nyeri & 32 & 69 & 101 & 66 & 35 & 0 & 1,36 \\
\hline & Fisioterapi & 0 & 1446 & 1446 & 39 & 1398 & 9 & 19,54 \\
\hline & Radioterapi & 28 & 182 & 210 & 84 & 126 & 0 & 2,84 \\
\hline & Hemodialisa & 8 & 24 & 32 & 0 & 32 & 0 & 0,43 \\
\hline & Jumlah & 2324 & 6312 & 8636 & 1206 & 7389 & 41 & 116,70 \\
\hline \multicolumn{2}{|c|}{ Total } & 2821 & 8114 & 10935 & 1475 & 9415 & 45 & 147,77 \\
\hline
\end{tabular}


Tabel 2

Kunjungan Rawat Jalan Rumah Sakit Universitas Hasanuddin

Triwulan II Tahun 2014 (75 Hr)

\begin{tabular}{|c|c|c|c|c|c|c|c|c|}
\hline No & $\begin{array}{l}\text { Jenis } \\
\text { Pelayanan }\end{array}$ & Baru & Lama & Jumlah & Umum & BPJS & Korporasi & $\begin{array}{l}\text { Rata- } \\
\text { rata } \\
\text { Perhari }\end{array}$ \\
\hline \multirow[t]{10}{*}{1} & \multicolumn{8}{|c|}{ Poliklinik Bedah } \\
\hline & Orthopedi & 123 & 288 & 411 & 48 & 362 & 1 & 5,48 \\
\hline & Digestif & 60 & 207 & 267 & 10 & 257 & 0 & 3,56 \\
\hline & Saraf & 29 & 94 & 123 & 7 & 115 & 1 & 1,64 \\
\hline & Anak & 6 & 68 & 74 & 28 & 46 & 0 & 0,99 \\
\hline & Onkologi & 246 & 986 & 1232 & 33 & 1199 & 0 & 16,43 \\
\hline & Plastik & 15 & 45 & 60 & 29 & 30 & 1 & 0,80 \\
\hline & Urologi & 63 & 444 & 507 & 11 & 492 & 4 & 6,76 \\
\hline & $\begin{array}{l}\text { Thorax \& } \\
\text { Cardio }\end{array}$ & 6 & 48 & 54 & 2 & 52 & 0 & 0,72 \\
\hline & Jumlah & 548 & 2180 & 2728 & 168 & 2553 & 7 & 36,37 \\
\hline \multirow[t]{17}{*}{2} & \multicolumn{8}{|c|}{ Poliklinik Non Bedah } \\
\hline & Saraf & 378 & 490 & 868 & 56 & 812 & 0 & 11,57 \\
\hline & Anak & 147 & 206 & 353 & 55 & 294 & 4 & 4,71 \\
\hline & Interna & 1112 & 1927 & 3039 & 211 & 2813 & 15 & 40,52 \\
\hline & THT & 374 & 380 & 754 & 149 & 601 & 4 & 10,05 \\
\hline & Obgyn & 222 & 387 & 609 & 82 & 524 & 3 & 8,12 \\
\hline & Psikiatrik/ Jiwa & 19 & 55 & 74 & 8 & 66 & 0 & 0,99 \\
\hline & Gizi & 18 & 1 & 19 & 0 & 19 & 0 & 0,25 \\
\hline & Kulkel & 49 & 166 & 215 & 44 & 168 & 3 & 2,87 \\
\hline & Mata & 644 & 2112 & 2756 & 234 & 2520 & 2 & 36,75 \\
\hline & Umum & 52 & 66 & 118 & 56 & 36 & 26 & 1,57 \\
\hline & Cardio & 302 & 221 & 523 & 19 & 501 & 3 & 6,97 \\
\hline & Klinik Nyeri & 27 & 71 & 98 & 19 & 67 & 12 & 1,31 \\
\hline & Fisioterapi & 21 & 1489 & 1510 & 5 & 1505 & 0 & 20,13 \\
\hline & Radioterapi & 112 & 2078 & 2190 & 613 & 1577 & 0 & 29,20 \\
\hline & Hemodialisa & 62 & 323 & 385 & 0 & 385 & 0 & 5,13 \\
\hline & Jumlah & 3539 & 9972 & 13511 & 1551 & 11888 & 72 & 180,15 \\
\hline \multicolumn{2}{|c|}{ Total } & 4087 & 12152 & 16239 & 1719 & 14441 & 79 & 216,52 \\
\hline
\end{tabular}


Mariati Rahman, Kualitas Layanan Kesehatan Pasien Peserta Badan Penyelenggara Jaminan Sosial

(BPJS) di Rumah Sakit Universitas Hasanuddin 137

Tabel 3

Kunjungan Rawat Jalan Rumah Sakit Universitas Hasanuddin

Triwulan III Tahun 2014 (71 Hr)

\begin{tabular}{|c|c|c|c|c|c|c|c|c|}
\hline No & $\begin{array}{l}\text { Jenis } \\
\text { Pelayanan }\end{array}$ & Baru & Lama & Jumlah & Umum & BPJS & Korporasi & $\begin{array}{l}\text { Rata-rata } \\
\text { Perhari }\end{array}$ \\
\hline \multirow[t]{10}{*}{$\mathbf{1}$} & \multicolumn{8}{|l|}{ Poliklinik Bedah } \\
\hline & Orthopedi & 157 & 331 & 488 & 47 & 441 & 0 & 6,87 \\
\hline & Digestif & 60 & 273 & 333 & 3 & 324 & 6 & 4,69 \\
\hline & Saraf & 26 & 87 & 113 & 1 & 111 & 1 & 1,59 \\
\hline & Anak & 43 & 109 & 152 & 44 & 106 & 2 & 2,14 \\
\hline & Onkologi & 257 & 1190 & 1447 & 17 & 1430 & 0 & 20,38 \\
\hline & Plastik & 25 & 109 & 134 & 5 & 129 & 0 & 1,89 \\
\hline & Urologi & 71 & 493 & 564 & 2 & 556 & 6 & 7,94 \\
\hline & $\begin{array}{l}\text { Thorax \& } \\
\text { Cardio }\end{array}$ & 4 & 64 & 68 & 2 & 66 & 0 & 0,96 \\
\hline & Jumlah & 643 & 2656 & 3299 & 121 & 3163 & 15 & 46,46 \\
\hline \multirow[t]{17}{*}{2} & \multicolumn{8}{|c|}{ Poliklinik Non Bedah } \\
\hline & Saraf & 362 & 727 & 1089 & 27 & 1060 & 2 & 15,34 \\
\hline & Anak & 128 & 276 & 404 & 74 & 323 & 7 & 5,69 \\
\hline & Interna & 1242 & 2634 & 3876 & 1637 & 2234 & 5 & 54,59 \\
\hline & THT & 445 & 610 & 1055 & 96 & 941 & 18 & 14,86 \\
\hline & Obgyn & 254 & 530 & 784 & 67 & 711 & 6 & 11,04 \\
\hline & Psikiatrik/ Jiwa & 31 & 59 & 90 & 9 & 80 & 1 & 1,27 \\
\hline & Gizi & 33 & 1 & 34 & 1 & 32 & 1 & 0,48 \\
\hline & Kulkel & 57 & 156 & 213 & 45 & 168 & 0 & 3,00 \\
\hline & Mata & 707 & 2377 & 3084 & 103 & 2980 & 1 & 43,44 \\
\hline & Umum & 48 & 60 & 108 & 32 & 40 & 36 & 1,52 \\
\hline & Cardio & 384 & 303 & 687 & 10 & 677 & 0 & 9,68 \\
\hline & Klinik Nyeri & 22 & 42 & 64 & 9 & 26 & 29 & 0,90 \\
\hline & Fisioterapi & 115 & 1822 & 1937 & 285 & 1652 & 0 & 80,71 \\
\hline & Radioterapi & 75 & 2748 & 2823 & 606 & 2217 & 0 & 117,63 \\
\hline & Hemodialisa & 95 & 746 & 841 & 1 & 840 & 0 & 35,04 \\
\hline & Jumlah & 3998 & 13091 & 17089 & 3002 & 13981 & 106 & 712,04 \\
\hline \multicolumn{2}{|c|}{ Total } & 4641 & 15747 & 20388 & 3123 & 17144 & 121 & 287,15 \\
\hline
\end{tabular}

